\title{
COMPARATIVE QUALITY ASSESSMENT OF PEANUT AND PEANUT-FLAXSEED OIL
}

\author{
Svitlana Lehnert \\ Department of Merchandising and Goods' Examination \\ Kharkiv State University of Food Technology and Trade \\ 333 Klochkivska str., Kharkiv, Ukraine, 61051 \\ svitlana.dubinina@googlemail.com \\ Antonina Dubinina \\ Department of Equipment and Engineering for Processing and Food Technologies \\ Kharkiv Petro Vasylenko National Technical University of Agriculture \\ 92 Myronosytska str., Kharkiv, Ukraine, 61002 \\ Gregoriy Deynichenko \\ Department of equipment for food and hospitality industry named after M. I. Belyaeva \\ Kharkiv State University of Food Technology and Trade \\ 333 Klochkovska str., Kharkiv, Ukraine, 61051 \\ Olga Khomenko \\ Department of merchandising and examination of goods \\ Kharkiv State University of Food Technology and Trade \\ 333 Klochkivska str., Kharkiv, Ukraine, 61051

\section{Oksana Haponceva} \\ Department of merchandising and examination of goods \\ Kharkiv State University of Food Technology and Trade \\ 333 Klochkivska str., Kharkiv, Ukraine, 61051

\section{Irina Antonyuk} \\ Department of Technology and the organization of restaurant business \\ Kyiv National University of Trade and Economics \\ 19 Kioto str., Kyiv, Ukraine, 02156

\section{Anzhelika Medvedieva} \\ Department of Technology and the organization of restaurant business \\ Kyiv National University of Trade and Economics \\ 19 Kioto str., Kyiv, Ukraine, 02156 \\ a.ai.medv@gmail.com

\section{Miroslava Demichkovska} \\ Department of Technology and the organization of restaurant business \\ Kyiv National University of Trade and Economics \\ 19 Kioto str., Kyiv, Ukraine, 02156

\section{Olena Vasylieva} \\ Department of Technology and the organization of restaurant business \\ Kyiv National University of Trade and Economics \\ 19 Kioto str., Kyiv, Ukraine, 02156
}

Abstract

The aim of research is quality assessment of peanut and peanut-flaxseed oil for organoleptic and physico-chemical indicators, as well as the study of fatty acid composition of fat. It will determine the consumer properties of these products. Comparative stud- 
ies of consumer properties of peanut and peanut-flaxseed oil for organoleptic indicators, fatty acid composition, acid and peroxide numbers are carried out. To determine the fatty acid composition of fat, the gas chromatography method is used. The measurement of the acidic and peroxide number of fat is performed by a titrimetric method.

The research results of organoleptic and physicochemical parameters, as well as the fatty acid composition of peanut oil and peanut-flaxseed blend have shown that the flavor qualities of the developed oil are balanced and high, therefore new oil can be consumed by consumers. The enrichment of peanut oil with flaxseed helps improve the fatty acid composition beyond the set of a significant increase in unsaturated fatty acids (linoleic by $23 \%$, oleic by $28 \%$, linolenic by $96 \%$ ). It has also been proved that the use of flaxseed oil does not have a significant effect on the acceleration of the hydrolytic processes of vegetable oil fats.

The expediency of mixing peanut and flaxseed oil is shown, which makes it possible to obtain new blended peanut-flaxseed oil, balanced by fatty acid composition.

Keywords: peanut-flaxseed oil, blending of oils, fatty acid composition of peanut-flaxseed oil.

(C) Svitlana Lehnert, Antonina Dubinina, Gregoriy Deynichenko, Olga Khomenko, Oksana Haponceva, Irina Antonyuk, Anzhelika Medvedieva,

\section{Introduction}

Balanced nutrition is one of the most pressing problems of mankind in the third millennium. Today, most products have an acute shortage of high-grade proteins, polyunsaturated fatty acids, vitamins, minerals, dietary fiber and other nutrients. A very good source of these substances is nutfruit [1]. But they have not yet found their full application for the production of healthy foods. A promising raw material for expanding the range of such products is peanuts. The proteins of which are characterized by a high content of essential amino acids, they brings them closer to animals. Peanuts are a source of vitamins and minerals, which positively affects the activity of the nervous system, heart, liver and other organs, accelerates the growth of cells [2]. The most important, in terms of nutritional value, in peanuts is an oil in which unsaturated acids predominate, which makes this nut an important product in the fight against atherosclerosis and other cardiovascular diseases, and also helps to reduce the level of excess cholesterol in the blood [3, 4].

Peanuts are distinguished by high annual yields, resistance to diseases and pests, and fat content. Peanut oils are characterized by high consumer properties, which explain the annual increase in demand from the population [5].

Recently, dietitians pay special attention to the composition of vegetable fats, that is, the ratio of saturated, monosaturated and polysaturated fatty acids in them. Peanut oil consists of mixed glycerides containing about $80 \%$ unsaturated (oleic, linoleic, traces of linolenic) and $20 \%$ saturated fatty acids [6]. The fatty acid composition of peanut oil determines its stability under the influence of high temperatures and resistance to oxidation during storage [7]. It should be noted that peanut oil practically does not contain linolenic fatty acids. In order to improve the consumer properties of vegetable oils, they are being developed to balance them with the blending method [8]. To increase the content of linolenic fatty acids in peanut oil, it is advisable to use flaxseed oil, which is characterized by a high content of omega-6-unsaturated fatty acids.

The aim of research is quality assessment of peanut and peanut-flaxseed oil for organoleptic and physico-chemical indicators, as well as the study of fatty acid composition of fat. This will make it possible to establish the expediency of using flaxseed oil in a peanut blend to obtain a balanced product for the prophylactic nutrition of a fatty acid composition.

\section{Material and Methods}

For the experiment, peanut and peanut-flaxseed oil are selected (Fig. 1), obtained from the varieties of peanut Krasnodar 14, Krasnodar 15, Pink Big, Pale Pink 2, AR 1, AR 2, which are characterized by high fat content and oil yield (Fig. 2-7).

With the help of mathematical modeling [9] it is established that to create blended oils with optimized fatty acid composition, such ratio of oils, $\%$ : peanut -86 , flaxseed -14 . The basis for the calculation of a balanced blend of oils is the requirements of dieticians for the fatty acid composition of oils, namely the ratio of MFA:PFA as 1:1, and $\omega-3: \omega-6$ as $1: 5$ (for therapeutic and prophy- 
lactic purposes). The maximum permissible concentration of flax oil in mixtures, which does not reduce their quality, is not more than $17.1 \%$ [10]. As a result of the determination of the fatty acid composition of the developed blend of vegetable oils, it is found that the content of unsaturated fatty acids is, $\%$ : oleic -46.8 ; palmitooleine $-0,17$; erucic $-0,04$; linoleic -37.22 ; linolenic -7.65 . The total content of unsaturated fatty acids in blended oil is $90.82 \%$, of which polyunsaturated is $44.81 \%$, with the ratio $\omega-6 \omega-3=4.8$ :, and the ratio of monounsaturated fatty acids to polyunsaturated fatty acids is $1: 1$, which corresponds to the recommended ratio of $\omega-6$ to $\omega-3$ fatty acids for therapeutic and preventive nutrition [9].

The technology of the developed oils does not differ from the traditional one and consists of the following stages: inspection, cleaning from the shell, grinding, conditioning by moisture content, pressing, filtration, packaging, marking and storage [11].

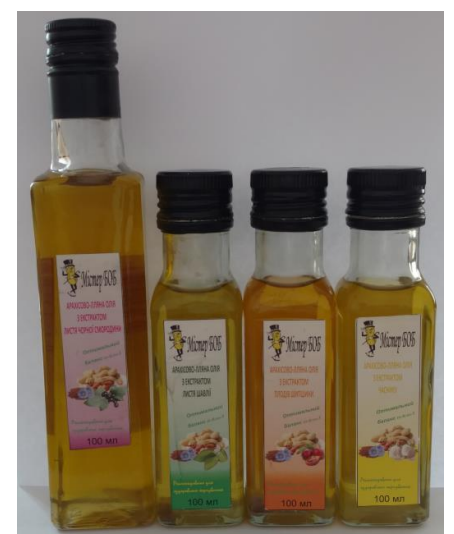

Fig. 1. Peanut flaxseed oil

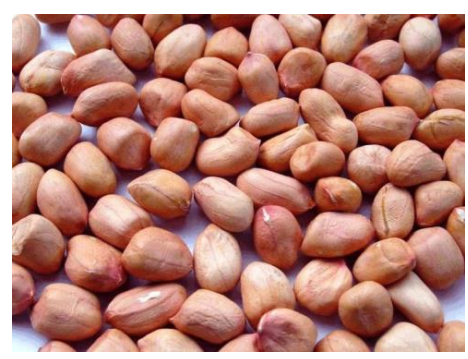

Fig. 2. Krasnodar 14 peanut

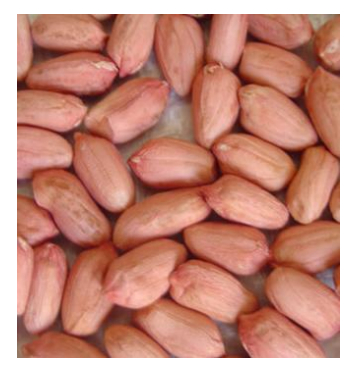

Fig. 3. Krasnodar 15 peanut

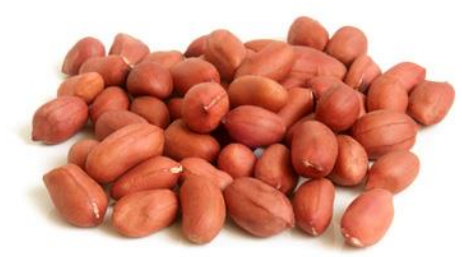

Fig. 4. Pink Big peanut 


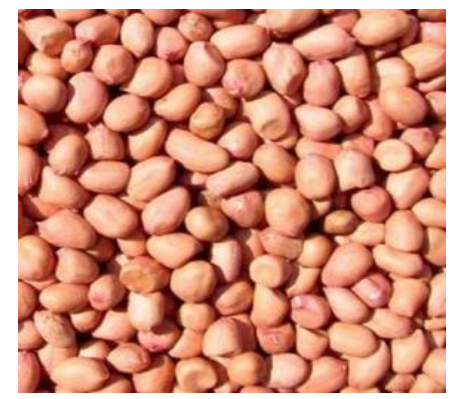

Fig. 5. Pale Pink peanut

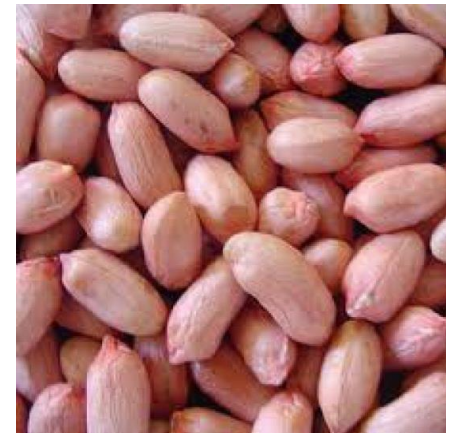

Fig. 6. AR 1 peanut

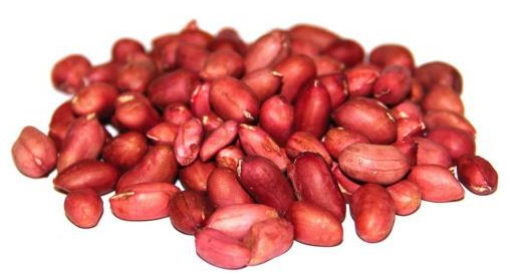

Fig. 7. AR 2 peanut

Organoleptic properties of oils are examined in accordance with DSTU 4536:2006 "Blended vegetable oils. Technical conditions »[12] and on a 5-point scale developed by the specialists of the Department of Commodity Research and Expertise of Goods of the Kharkiv State University of Nutrition and Trade (Table 1). For the tasting assessment of the quality of oils, an expert commission is compiled from six faculty members. The following parameters are evaluated: appearance, taste and smell. When evaluating the appearance of the product, attention is paid to its homogeneity, turbidity presence, sediment and foreign inclusions. Color is determined by visual inspection. In the study of taste and smell, the harmony, intensity, specificity, and the presence of specific and extraneous tastes and smells are evaluated [13].

The acid number of blended oil is determined by the titration method in the titration unit (Fig. 8). The essence of the method consists in dissolving a certain mass of oil in a mixture of organic solvents (ethyl alcohol), followed by titration of free fatty acids with an aqueous or alcoholic solution of potassium hydroxide or sodium [14].

A test oil sample of 2.5 to $10 \mathrm{~g}$ was placed in a conical flask with a capacity of $250 \mathrm{~cm}^{3}$, depending on the expected acid value. In the second flask, $150 \mathrm{~cm}^{3}$ of ethyl alcohol containing $0.5 \mathrm{~cm}^{3}$ of phenolphthalein was heated to boiling. At an ethyl alcohol temperature above $70{ }^{\circ} \mathrm{C}$, it was gently neutralized with a solution of potassium hydroxide and titrated until the color changes, non-vanishing for 15 seconds. Neutralized ethyl alcohol was poured into the first flask with a research probe and mixed thoroughly. The contents of the flask were brought to the boiling point and titrated with a solution of potassium hydroxide (at a concentration of $0.1 \mathrm{~mol} / \mathrm{dm}^{3}$ or $0.5 \mathrm{~mol} / \mathrm{m}^{3}$, depending on the expected acid value) until a stable crimson color of the solution. 
Table 1

Scores of organoleptic parameters of oil quality

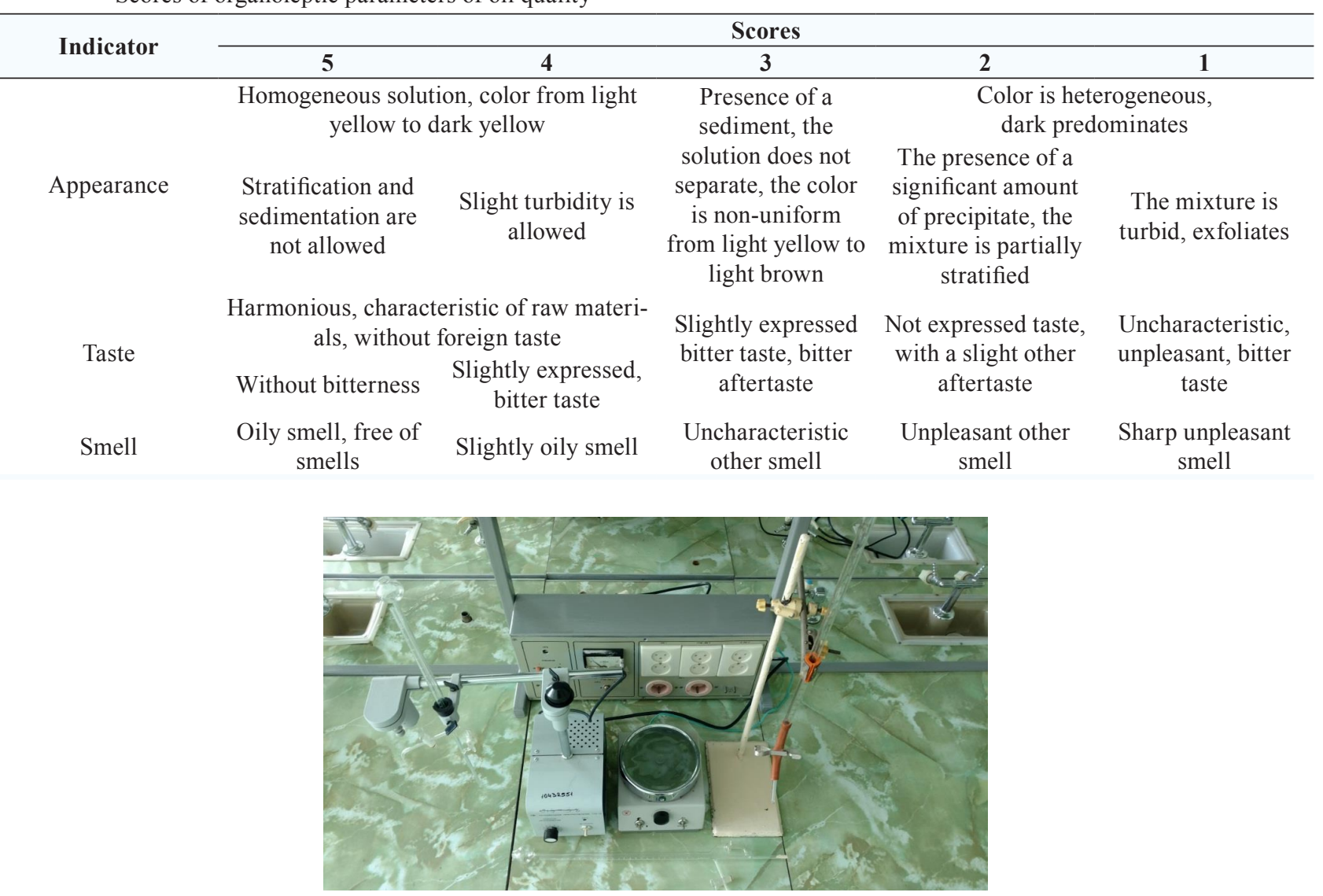

Fig. 8. Titrated installation TPR-M-UHL 4.2 (Ukraine)

The acid number (mg KOH/g) is calculated by the formula:

$$
\mathrm{AN}=\frac{\mathrm{C} \times \mathrm{V} \times 56,1}{\mathrm{~m}}
$$

where $\mathrm{C}$ - the exact value of the molar concentration of the alkali titrate, $\mathrm{mol} / \mathrm{dm}^{3}, \mathrm{~V}$ - the volume of alkaline titrant determined during the indicator titration, $\mathrm{cm}^{3}, 56.1$ - the molar mass of potassium hydroxide, $\mathrm{g} / \mathrm{mol} ; \mathrm{m}$ - oil weight, $\mathrm{g}$.

The peroxide number was measured by a titrimetric method [15]. The sample mass was measured from 1.0 to $2.0 \mathrm{~g}$. The sample was weighed into a conical flask, $10 \mathrm{~cm} 3$ of chloroform was added, rapidly dissolved, $15 \mathrm{~cm}^{3}$ of acetic acid and $1 \mathrm{~cm}^{3}$ of potassium iodide solution were added, then immediately closed, stirred for $1 \mathrm{~min}$ and left for 5 minutes in a dark place at a temperature of $15-20^{\circ} \mathrm{C}$. Then $75 \mathrm{~cm}^{3}$ of water was added, thoroughly mixed and a starch solution added until a weak, uniform violet-blue color appeared. The released iodine was titrated with a solution of sodium thiosulfate until milky white, stable for 5 seconds. The peroxide number $\mathrm{X}$ in mole $\mathrm{kg} 1 / 2 \mathrm{O}$ was calculated by the formula:

$$
\mathrm{X}=\frac{(\mathrm{V} 1-\mathrm{V} 0) \times \mathrm{C} \times 1000}{\mathrm{~m}}
$$

where $\mathrm{V}_{0}$ - the volume of the solution of sodium thiosulfate for control titration, $\mathrm{cm}^{3} ; \mathrm{V}_{1}$ - the volume of the solution of sodium thiosulfate during the measurement, $\mathrm{cm}^{3} ; \mathrm{C}$ - the true concentration of the used sodium thiosulfate solution, calculated taking into account the correction to the nominal 
concentration, $\mathrm{mol} / \mathrm{dm}^{3} ; \mathrm{m}$ - oil weight, g, 1000 - factor, taken into account when recalculating the result of measurement in mg per kilogram.

The fatty acid composition of fat was determined by gas chromatography, based on the separation of methyl esters of fatty acids using a Chrom-5 gas chromatograph (Czech Republic) (Fig. 9).

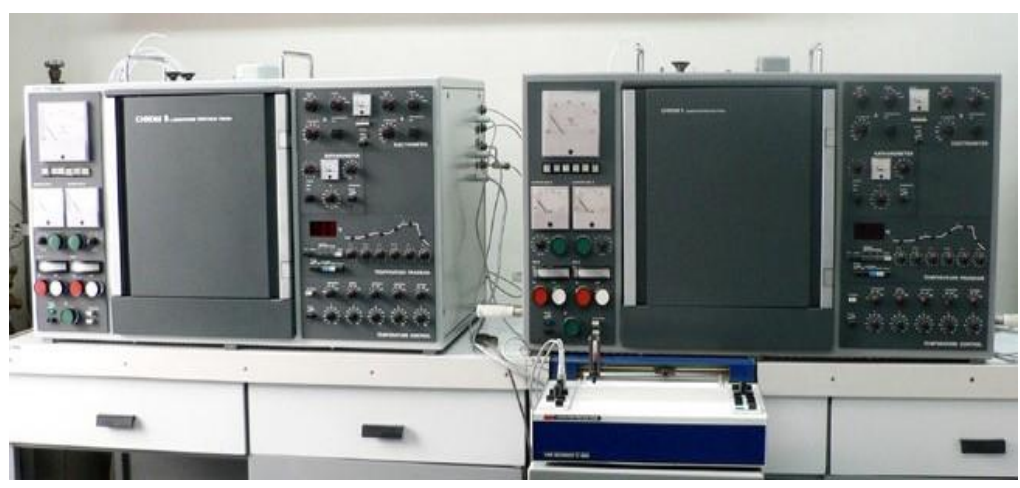

Fig. 9. «Chrom-5» gas chromatograph

The first stage of the study was the production of methyl esters of fatty acids. To the sample of $0.1 \mathrm{~g}$ of oil, placed in a glass with a capacity of $19 \mathrm{~cm}^{3}$, add $0.5 \mathrm{~cm}^{3}$ of methanol or absolute standard and one granule of potassium hydroxide. The glass is tightly closed with a stopper and kept at room temperature $\left(20-22{ }^{\circ} \mathrm{C}\right)$ for at least 24 hours for hydrolysis. Then, sulfuric acid is added dropwise, concentrated to $\mathrm{pH} 4.0-5.0$. To the resulting methyl esters of fatty acids, $0.02 \mathrm{~g}$ of distilled dibutyl phthalate is added, weighted to within $+/-0.0002$, used as the internal standard.

At the second stage, chromatographic determination of 1-3 $\mu$ l of methyl esters of fatty acids was carried out and introduced into a gas-liquid chromatograph evaporator having a temperature of $300{ }^{\circ} \mathrm{C}$. The temperature of the column thermostat is programmed in the range $150-200{ }^{\circ} \mathrm{C}$ with a rate of change of temperature of $5 \mathrm{deg} / \mathrm{min}$, the carrier gas (nitrogen) velocity is $30 \mathrm{ml} / \mathrm{min}$. The identification of methyl esters of fatty acids was carried out by comparing the retention times of the sample peaks and the control mixture of methyl esters of fatty acids. The mass fraction of the acids considered is calculated by the formula:

$$
\mathrm{X}=\frac{\mathrm{S} 1 \times \text { M.f.a. } \times 100 \%}{\mathrm{~S} 2 \times \text { M.e.f.a. } \times \mathrm{a}}
$$

where $\mathrm{X}$ - the mass fraction of fatty acids, $\mathrm{mg}, \mathrm{S} 1$ - the area of the fatty acid peak, $\mathrm{mm}^{2} ; \mathrm{S} 2$ - the area of the standard peak, mg; M.f.a. - relative molecular weight of fatty acid, a.s.m; M.e.f.a. - relative molecular weight of the fatty acid ester, a.s.m.; a - weight of the fat sample, mg; 100 - conversion factor per $100 \mathrm{mg}$ [16].

The repetition of all the experiments was threefold. The research results were processed using mathematical statistics and correlation analysis on a PC using Microsoft Word 2010, Microsoft Excel 2010 and Math Cad 14 Ful.

\section{Results. Comparative quality assessment of peanut and peanut-flaxseed oil}

A comparative assessment of the quality of peanut and peanut-flaxseed oil was carried out for organoleptic, physicochemical indicators, and their fatty acid composition was studied. The results of the organoleptic quality assessment of peanut oil (control) and the developed peanut-flaxseed blend are given in Table 2.

As a result of the organoleptic assessment, it is established that pure peanut oil is inferior to the taste properties of the developed peanut-flaxseed blend of oils. It can be argued that the introduction of flaxseed oil in an amount of $14 \%$ does not negatively affect the palatability of the new oil. Tasters assessed peanut-flaxseed oil to be 4.9 balls out of the maximum possible 5 . 
Table 2

Organoleptic quality assessment of peanut and peanut-flaxseed oil

\begin{tabular}{ccc}
\hline Indicator & Peanut oil & Sample \\
\cline { 2 - 3 } Appearance & $\begin{array}{c}\text { Oily liquid of light yellow color with a } \\
\text { slight sediment }\end{array}$ & $\begin{array}{c}\text { Transparent homogeneous oily liquid, without } \\
\text { sediment and foreign impurities, light yellow with a } \\
\text { greenish tinge }\end{array}$ \\
Taste & $\begin{array}{c}\text { Harmonious, characteristic of raw } \\
\text { materials, weakly expressed }\end{array}$ & $\begin{array}{c}\text { Harmonious, characteristic of raw materials, without } \\
\text { bitterness and foreign taste }\end{array}$ \\
Smell & Slightly oily smell & Oily smell, free of other smells \\
Score & 4.4 & 4.9
\end{tabular}

The second stage of the work involved measuring the acidic and peroxide number of fat in peanut and peanut-flaxseed oil. During storage in the oil, hydrolytic processes occur that significantly degrade the quality of the products.

Indicators of oxidation processes in fats are acidic and peroxide numbers of fat. It is known that flaxseed oil is unstable and easily oxidized during storage. Therefore, it was sensible to study the change in physical and chemical parameters when adding flaxseed oil to peanut oil. Shelf life of vegetable oils (sunflower, olive, peanut, etc.) is 1-2 years, and flaxseed - from 3 to 12 months. In order to determine the dynamics of the content of acidic and peroxide fat in the test samples, it is expedient to carry out periodically during storage: immediately after the bottling, after 3 months of storage, after 6 months, 9 and 12 months later. The results of the study of fresh oil and after storage for 3 months are shown in Table 3. It is also planned to carry out research on changes in the quality of oils during further storage (Table 3).

Table 3

Determination of acid and peroxide number of fat in peanut and peanut-flaxseed oil

\begin{tabular}{ccccc}
\hline \multirow{2}{*}{ Indicator } & \multicolumn{2}{c}{ Peanut oil } & \multicolumn{2}{c}{ Peanut-flaxseed oil } \\
\cline { 2 - 5 } & 0 month & 3 month & 0 month & 3 month \\
\hline Acid number, $\mathrm{mg} \mathrm{KOH} / \mathrm{g}$ & 1.3 & 1.5 & 1.4 & 1.6 \\
Peroxide number, $1 / 2 \mathrm{O} \mathrm{mmol} / \mathrm{kg}$ & 3.0 & 3.3 & 3.3 & 3.6
\end{tabular}

An analysis of the results shows that the acidic fatty acid content of peanut-flaxseed oil is only $5 \%$ higher than peanut oil, and peroxide number $-8.5 \%$. During the storage for 3 months, the acidity of peanut oil and peanut-flaxseed blend increased by $12 \%$, and peroxide number - by $8 \%$ and $9 \%$, respectively. Comparing the obtained results, it can be stated that the application of flaxseed oil does not significantly affect the amount of acidic and peroxide fat amount of the developed blend during storage for 3 months.

In order to compare the biological value of the oil, the fatty acid composition of the oil samples is studied, namely the content of unsaturated fatty acids - oleic, linoleic and linolenic, by gas-liquid chromatography after 3 months of oil storage. The results are given in Table 4.

Table 4

Fatty acid composition of peanut and peanut-flaxseed oil

\begin{tabular}{ccc}
\hline Indicator & Peanut oil & Peanut-flaxseed oil \\
\hline Oleic, $\mathrm{g} / 100 \mathrm{~g}$ & 28.6 & 39.8 \\
Linoleic, $\mathrm{g} / 100 \mathrm{~g}$ & 25.3 & 32.8 \\
Linolenic, $\mathrm{g} / 100 \mathrm{~g}$ & 0.4 & 10.7
\end{tabular}


As a result of the research it is established that the developed blend of peanut-flaxseed oil contains more unsaturated fatty acids in comparison with peanut oil. For example, the content of oleic acid in the developed blend is $28 \%$ higher than in peanut oil. Linoleic fatty acids are also larger by $23 \%$ in peanut-flaxseed oil than in pure peanut oil. Thanks to the introduction of flaxseed oil, it is possible to enrich the new oil with linolenic fatty acids, which became more by $96 \%$ than in pure peanut oil.

\section{Conclusions}

1. Comparative assessment of organoleptic indicators indicates that the use of flaxseed oil to enrich peanut oil does not adversely affect the flavor and aromatic properties of vegetable oil, but, on the contrary, contributes to its balance.

2. The acid and the peroxide number of the fat peanut, peanut and flaxseed oil are located substantially in the same range. Because it is possible that the introduction of flaxseed oil does not accelerate hydrolytic processes blended egg fat in the vegetable oil.

3. The expediency of enrichment peanut oil by flaxseed is shown, thereby significantly increasing the content of unsaturated fatty acids, especially linolenic, and hence improved biological value of the vegetable oil.

The research results of the quality of peanut and peanut-flaxseed oils allow to assess their biological value, to predict the change in quality during storage. In order to establish the patterns of acid and peroxide changes in fat, fatty acid and vitamin composition of peanut-flaxseed blends, further experiments are planned during long-term storage.

Comparative assessment of peanut and peanut-flaxseed oil confirm whether enrichment peanut flaxseed oil. This allows to increase the content of unsaturated fatty acids (oleic, linoleic, linolenic). The obtained results of acidic and peroxide number make it possible to predict with a high probability the nature of the changes in the quality of the developed blend during storage and culinary processing of raw materials.

\section{References}

[1] Dubinina, A. A., Lenert, S. O., Khomenko, O. O. (2013). Vykorystannia arakhisu u vyrobnytstvi produktiv funktsionalnoho pryznachennia. Prohresyvni tekhnika ta tekhnolohiyi kharchovykh vyrobnytstv restorannoho hospodarstva i torhivli, 1, 109-116.

[2] Dubinina, A. A., Lenert, S. O., Khomenko, O. O. (2013). Analysis of vitamin and mineral composition peanut varieties common in Ukraine. Eastern-European Journal of Enterprise Technologies, 6 (11 (66)), 4-7. Available at: http://journals.uran.ua/eejet/article/view/18858/17002

[3] Awad, A. B., Chan, K. C., Downie, A. C., Fink, C. S. (2000). Peanuts as a Source of $\beta$-Sitosterol, a Sterol With Anticancer Properties. Nutrition and Cancer, 36 (2), 238-241. doi: 10.1207/s15327914nc3602_14

[4] Grosso, N. R., Lucini, E. I., López, A. G., Guzmán, C. A. (1999). Chemical composition of aboriginal peanut (Arachis hypogaea L.) seeds from Uruguay. Grasas y Aceites, 50 (3), 203-207. doi: 10.3989/ gya.1999.v50.i3.657

[5] Tereshchuk, L. V., Pavlov, S. S. (2011). Sostav i svoystva semyan arahisa i produkty ego pererabotki. Konditerskoe proizvodstvo, 3, 20-21.

[6] Grosso, N. R., Zygadlo, J. A., Burroni, L. V., Guzmán, C. A. (1997). Fatty acid, sterol and proximate compositions of peanut species (Arachis L.) seeds from Bolivia and Argentina. Grasas y Aceites, 48 (4), 219-225. doi: 10.3989/gya.1997.v48.i4.792

[7] Shcherbakov, V. G. (2003). Biohimiya i tovarovedenie maslichnogo syr’ya. Moscow: Kolos, 360.

[8] Lukin, A. A., Pirozhinskiy, S. G. (2013). Perspektivy sozdaniya rastitel'nyh masel funkcional'nogo naznacheniya. Molodoy ucheniy, 9, 57-59.

[9] Dubinina, A. A., Lenert, S. O., Khomenko, O. O. (2014). Nova kupazhovana oliya z optymizovanym zhyrnokyslotnym skladom. Naukovi pratsi NUKhT, 20 (4), 211.

[10] Boeva, A. Yu. (2010). Formirovanie uluchshennyh potrebitel'skih svoystv kulinarnyh izdeliy na osnove morskoy kapusty putem sovershenstvovaniya ih sostava i tekhnologii proizvodstva. Moscow, 28.

[11] Cherevko, O. I., Dubinina, A. A., Deinychenko, H. V., Lenert, S. O., Khomenko, O. O. (2015). Pat. No. 113801 S2 UA. Kupazhovana oliya z roslynnym ekstraktom. MPK (2017.01) A23D9/00. No. a201510160; declareted: 19.10.2015; published: 10.03.2017, Bul. No. 5. 
[12] DSTU 4536:2006. Oliyi kupazhovani. Tekhnichni umovy (2007). Kyiv, 26.

[13] DSTU ISO 11035:2005. Doslidzhennia sensorne. Identyfikatsiya ta vybyrannia deskryptoriv dlia stvorennia sensornoho spektru za bahatobichnoho pidkhodu (2007). Kyiv, 34.

[14] DSTU 4350:2004. Oliyi. Metodyvyznachennia kyslotnoho chysla (2006). Kyiv, 12.

[15] GOST 26593-85. Masla rastitel'nye. Metod izmereniya perekisnogo chisla (2001). Moscow, 5.

[16] GOST 30418-96. Masla rastitel'nye. Metod opredeleniya zhirno-kislotnogo sostava (1997). Minsk, 7.

\title{
INVESTIGATION OF THE WATER-RETAINING CAPACITY OF THE CARBOHYDRATE COMPLEX OF RYE-WHEAT DOUGH WITH ADDITION OF POLYFUNCTIONAL FOOD SUPPLEMENT "MAGNETOFOOD"
}

\author{
Iryna Tsykhanovska \\ Department of food and chemical technologies \\ Ukrainian Engineering-Pedagogics Academy \\ 16 Universitetska str., Kharkiv, Ukraine, 61003 \\ cikhanovskaja@rambler.ru \\ Victoria Evlash \\ Department of Chemistry, Microbiology and Food Hygiene \\ Kharkiv State University of Nutrition and Trade \\ 333 Klochkivska str., Kharkiv, Ukraine, 61051 \\ evlashvv@gmail.com \\ Alexandr Alexandrov \\ Department of food and chemical technologies \\ Ukrainian Engineering-Pedagogics Academy \\ 16 Universitetska str., Kharkiv, Ukraine, 61003 \\ alexandrov.a.v.a.v@gmail.com

\section{Tetiana Lazareva} \\ Department of food and chemical technologies \\ Ukrainian Engineering-Pedagogics Academy \\ 16 Universitetska str., Kharkiv, Ukraine, 61003 \\ Lazareva_T.A@ukr.net

\section{Tetiana Yevlash} \\ Department of Accounting, Audit and Taxation \\ Kharkiv State University of Nutrition and Trade \\ 333 Klochkivska str., Kharkiv, Ukraine, 61051 \\ tanya@evlash.org.ua
}

\footnotetext{
Abstract

Today in Ukraine the share of low-quality bakery products is near 20-25\%, because they often don't correspond to quality standards and sanitary norms, because of being produced of flour with low bakery properties. That is why new raw material sources, functional ingredients and so on are searched for in bread technologies. For using new raw material and food supplement types, it is necessary to know their functional-technological properties (FTP) that allows to prognosticate the behavior of powder-like raw materials and food supplements in food masses at technological processing and storage of ready products.

The water-retaining capacity (WRC) is one of main functional-technological parameters of carbohydrate-containing raw materials, because it favors the outcome, structural-mechanical properties and quality characteristics of ready products.
} 